\title{
New CULTIVARS
}

Keywords: cultivar: Dionaea muscipula 'Fondue', Sarracenia 'Godzuki', Utricularia 'M errie Heart'.

\section{Dionaea muscipula 'Fondue'}

Submitted: $22 \mathrm{M}$ arch 2011

Dionaea muscipula 'Fondue' was found at the Carniflora open day on M ay 17, 2008. The most spectacular feature of this new cultivar is the strange shape of the traps - they look like molten or melted plastic (see Fig. 1). D uring spring, the traps can look like the typical Venus flytrap, but during summer and autumn most of the later traps look molten (see Fig. 2), even petioles can appear molten (see Fig. 3). Sometimes plants do not produce typical traps in the spring, but directly produce molten traps. B ecause of the shape of the traps, this Venus flytrap does not catch much prey so the inside of the traps are a deep red color during most of the year. Fondue means molten in French. Vegetative propagation is necessary to maintain the unique features of this plant.

— Guillaume Bily • 10 allée des pétrels•56520 Guidel•France•gbily2003@yahoo.fr
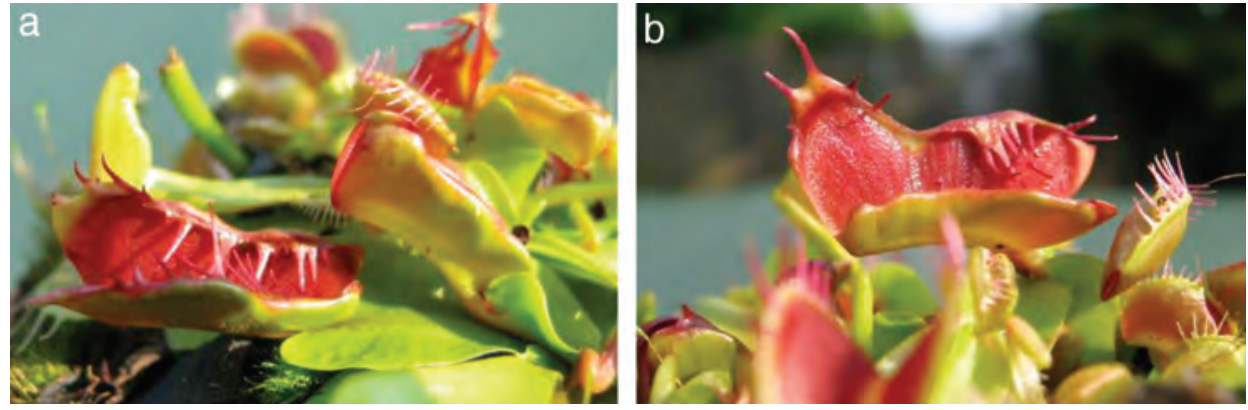

Figure 1: Molten traps of Dionaea muscipula 'Fondue'.

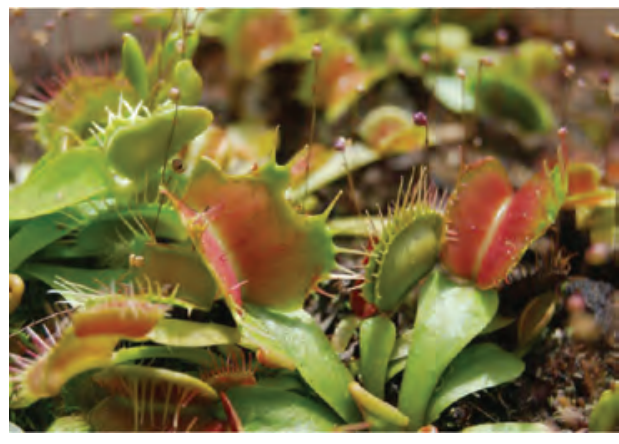

Figure 2: Normal and molten traps of Dionaea muscipula 'Fondue'.

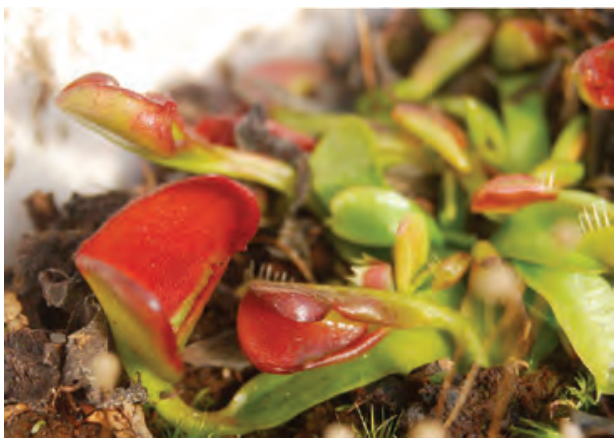

Figure 3: Molten petioles of Dionaea muscipula 'Fondue'. 


\section{Sarracenia 'Godzuki'}

Submitted: 13 J une 2011

$M$ any years ago I received this clone from Tom $K$ ahl, who had received it from L eo Song. Leo managed the greenhouses at California State U niversity at Fullerton for many years and was also co-editor of CPN for a long time.

Sarracenia 'Godzuki' is a clonal selection of a cross L eo did between S. oreophila and S. minor (S. oreophila $\times$ minor). M y nursery California Carnivores has sold and distributed many of these plants under the hybrid name Sarracenia oreophila $\times$ minor.

Sarracenia 'Godzuki' is a vigorous, fast-growing plant that readily spreads and clumps in cultivation, producing many pitchers throughout the growing season. The pitchers average about $25 \mathrm{~cm}$ in height, but can reach up to $45 \mathrm{~cm}$. The domed, semi-curved lid completely covers the mouth and its exterior is heavily veined and becomes copper red in full sun, while the interior becomes equally flushed with a bronze-red coloration. As it ages, the entire tube of the pitcher can become rather bronzy red against a green to olive background.

Several things are particularly noteworthy in S. 'Godzuki'. The medium-sized bright yellow/ green flowers open simultaneously with the opening of the first pitchers of the season (see Fig. 4 and Front Cover). The flower petals can last in prime condition for up to three weeks, around three times longer than typical A merican pitcher plants.

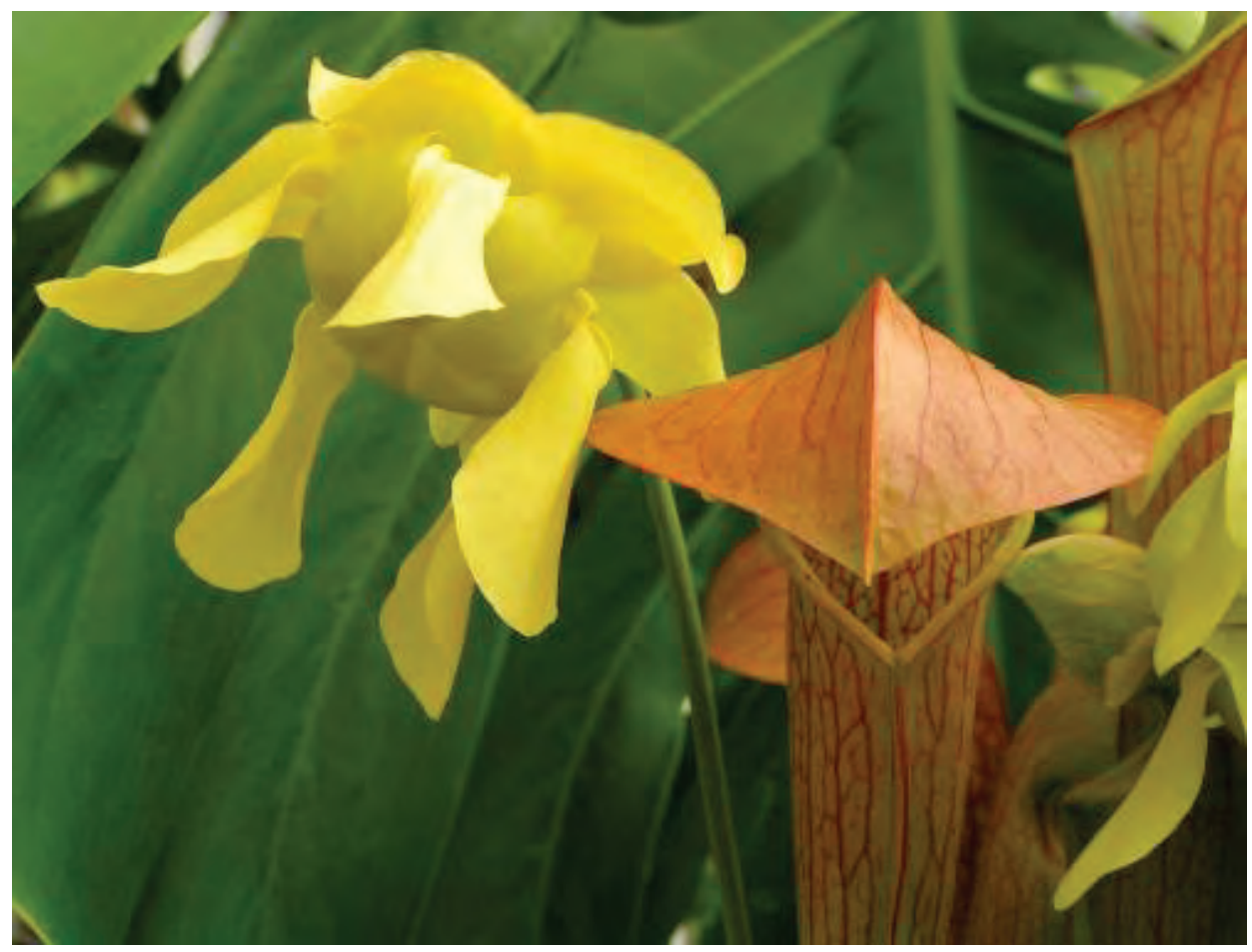

Figure 4: Sarracenia 'Godzuki' pitcher and flower. Photo by Damon Collingsworth 
It is most unusual, but we have never seen pollen released by the anthers, however the stigmas are receptive to the pollen of other Sarracenia.

Clumps of this clone can produce a floriferous display in spring. All of the pitchers face inward, toward the center growth point of the plant. The plant is very cold hardy, since S. oreophila is one of its parents.

It is the lizard-like appearance of S. 'G odzuki' that inspired us to name this clone after the son of Godzilla, a famous character in many Toho Film Productions.

- Peter D’Amato • California Carnivores • 2833 Old Gravenstein H wy • Sebastopol, CA 95472

-USA・califcarn@aol.com

\section{U tricularia 'M errie Heart'}

Submitted: 13 J une 2011

U tricularia livida is a popular plant in cultivation, however most clones of this species originated from South A frica. Strangely enough, this species is also widespread throughout M exico.

The Mexican variety is even more attractive in flower than the African variety and is equally easy to grow. It flowers prolifically, most often from spring through autumn, but it can bloom in winter as well if kept warm and in high light levels. It is tolerant of light frost and brief freezes.

The flower stalks average 7.5 to $15 \mathrm{~cm}$ in height but can be taller, with upper portions of the stalk each lasting several weeks in bloom. The flower's apron-like lower lip is slightly irregular along its edge, suffused with purpleviolet coloration, and measures nearly $1 \mathrm{~cm}$ across (see Fig. 5). The tiny upper lip is two-pronged. The forward facing curved spur is hidden below the larger lower lip and is also violet in color.

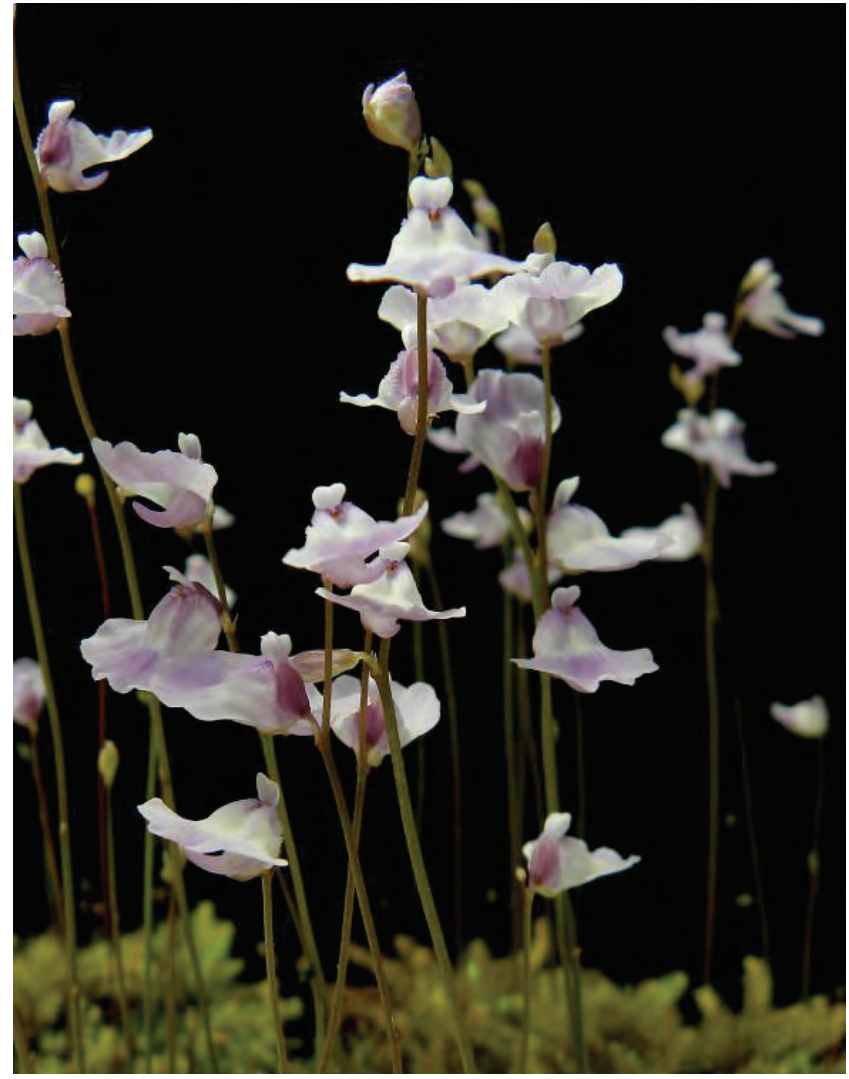

Figure 5: Utricularia 'Merrie Heart' flowers. 
There is no yellow throat in the spur, as in its A frican sibling. It has never produced seed to my knowledge, but is easily propagated through divisions. The sizeable surface stolon are irregularly tear-drop shaped and measure roughly $1 \mathrm{~cm}$ in length.

We have named this plant U tricularia 'M errie Heart' after the affectionate spelling Francis Ernest L loyd used for his beloved wife, $M$ ary Hart. M ary was born N ovember 6, 1865 in B oston, M assachusetts and was a graduate of Wellesley College. She was a professor of Biology at the Western College for Women, in Oxford, Ohio until she married Lloyd in 1903. She died in 1948 in Carmel, California.

Lloyd's obsession was U tricularia, and U. Iloydii is named after him. The L loyds lived in M exico for some years. See my article "Lloydie" in CPN, Vol. 39, N o. 2, June 2010.

-Peter D’Amato • California Carnivores • 2833 Old Gravenstein H wy • Sebastopol, CA 95472 -USA・califcarn@aol.com

\section{Ferocious Foliage.com Custom Tissue Culture Laboratory}

* In vitro propagation of plants from material you provide

* Cloning and mass production

* Induced polyploidy, gibberellic acid and smoke water treatment

* Custom rooting of Nepenthes (your plants or our stock)

Why would you want these services?

* For very difficult species, have a lot of individuals to experiment with

* Propagate unique clones to share or sell

* Decrease risk of germination failure, especially if you have few seeds

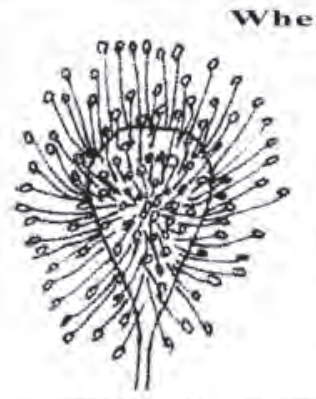

\section{California Carnivores}

Specializing in inseet-cating and other exotic plants

* Open all year, call ahead in winter

* Commercially cultivated

* Over 500 varieties on display

* On site \& domestic mail order

* We ship potted plants

2833 Old Gravenstein Hwy, Sebastopol, CA 95472 (707) 824-0433

Visit us on the Internet at http://californiacarnivores.com 


\section{CARNIVOROUS PLANT NEWSLETTER}

Journal of the International Carnivorous Plant Society

Volume 40, No. 3

September 2011

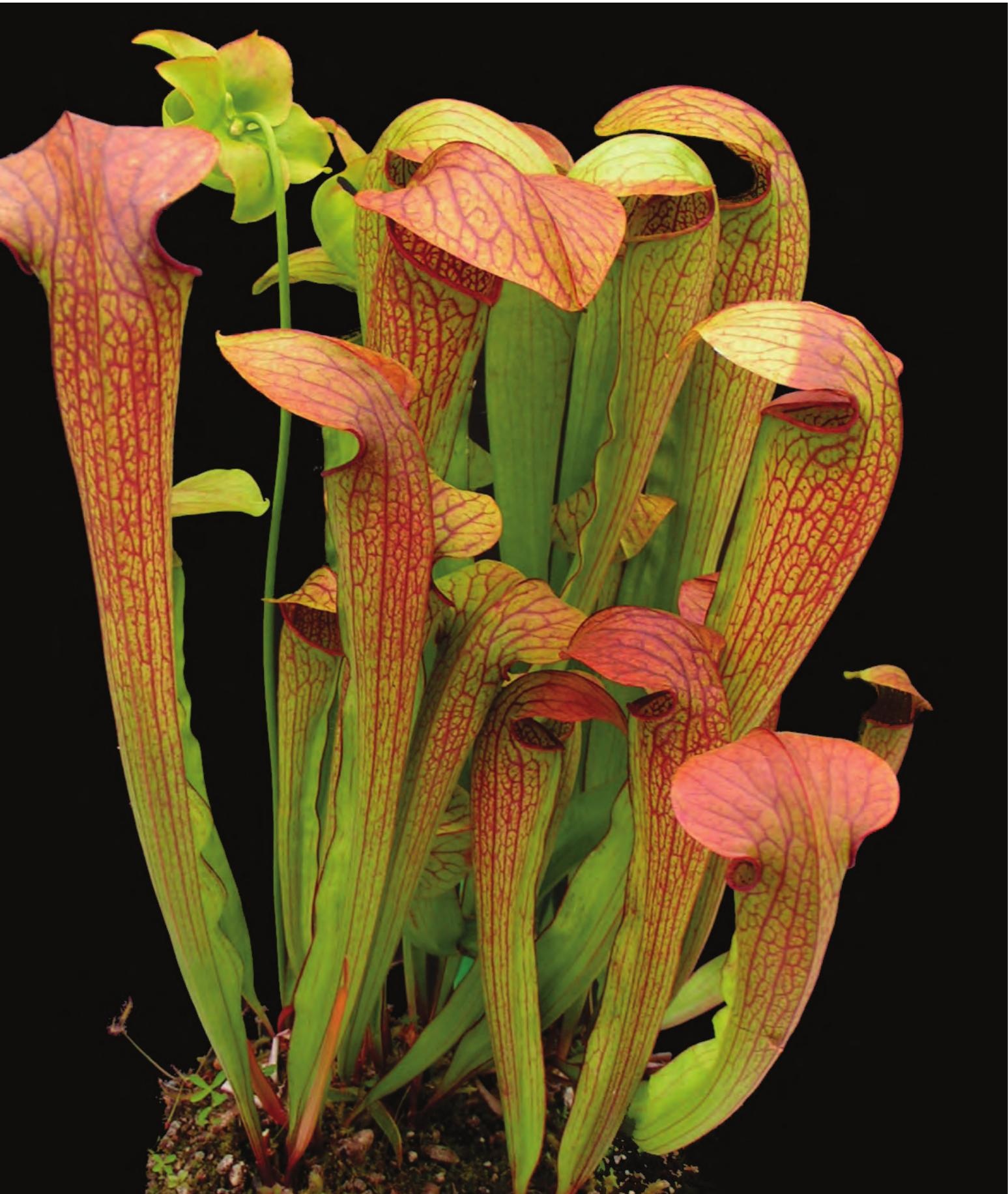




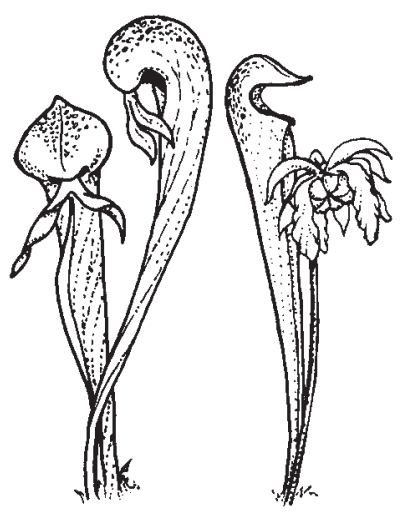

\section{CARNIVOROUS \\ PLANT \\ NEWSLETTER}

Journal of the International

Carnivorous Plant Society

www.carnivorousplants.org

Volume 40, Number 3 September 2011

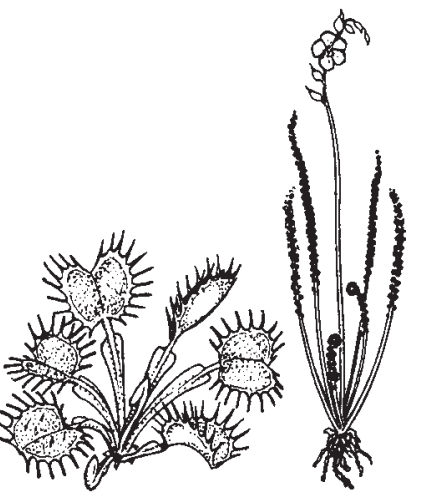

Front Cover: The cultivar Sarracenia ‘Godzuki’. Photo by Damon Collingsworth. Article on page 96.

Back Cover: Sarracenia leucophylla, Tate's Hell Swamp, north Florida. Photo by Brian Barnes. Article on page 92.

Carnivorous Plant Newsletter is dedicated to spreading knowledge and news related to carnivorous plants. Reader contributions are essential for this mission to be successful. Do not hesitate to contact the editors with information about your plants, conservation projects, field trips, or noteworthy events. A dvertisers should contact the editors. Views expressed in this publication are those of the authors, not the editorial staff.

All correspondence regarding dues, address changes and missing issues should be sent to the Membership Coordinator at the ICPS. D o not send such correspondence to the editors. Checks for subscriptions should be made to the ICPS in US funds. Dues for 2011 are $\$ 35$ for the first year of membership; renewals are $\$ 30$ per year.

ICPS, Inc.

2530 Patra Drive

Richmond, CA 94803, USA

icps@carnivorousplants.org

President Michael Baldwin, michael@ carnivorousplants.org

Vice President M Marcel van den B roek, marcel@ carnivorousplants.org

Secretary Cindy Slezak, cindy@ carnivorousplants.org

Treasurer Richard M yers, richard@ carnivorousplants.org

B oard M ember Bob Ziemer, bob@carnivorousplants.org

Board M ember Jan Schlauer, jan@ carnivorousplants.org

B oard M ember B B Bian Barnes, Conservation Director, brian@ carnivorousplants.org

Seed B ank M anager J ohn B rittnacher, john@ carnivorousplants.org (see seed bank ad in this issue)

Editors:

M anaging Editor

Science Editor

B ob Ziemer, bob@carnivorousplants.org

Jan Schlauer, jan@ carnivorousplants.org

Science Editor Fernando Rivadavia, fernando@ carnivorousplants.org

Editor

Barry Rice, barry@ carnivorousplants.org

Date of effective publication of the J une 2011 issue of Carnivorous Plant N ewsletter: 1 J une 2011.

The ICPS is the International Cultivar Registration A uthority (ICRA) for the names of cultivated carnivorous plants according to the International Code of N omenclature for Cultivated Plants. Send relevant correspondence to the ICPS, Inc.

Carnivorous Plant N ewsletter is published quarterly in M arch, J une, September, and December by the ICPS, Inc., 2530 Patra Drive, Richmond, CA 94803, USA. Periodicals postage pending at Richmond, CA and additional mailing offices. Postmaster: Send address changes to ICPS, Inc., PM B 322, 1564-A Fitzgerald Drive, Pinole, CA 94564-2229, USA. Printed by Allen Press, Inc., 810 E. 10th Street, L awrence, K S 66044. L ogo and masthead art: Paul M ilauskas. (c) 2011 Carnivorous Plant N ewsletter. All rights reserved. ISSN \#0190-9215 